\title{
THE INFLUENCE OF TIME PRESSURE, ROLE AMBIGUITY, WORKLOAD AND LACK OF MOTIVATION ON EMPLOYEE PERFORMANCE
}

\author{
KAREL TJAHJADI \\ FINKA PUTRIANA CAHYADI \\ Trisakti School of Management, Jl. Kyai Tapa No. 20, Grogol, Jakarta Barat, Indonesia \\ finkaputriana@yahoo.com, kareltjahjadi@yahoo.com
}

\begin{abstract}
This study aimed to determine the influence of Time Pressure, Role Ambiguity, Workload, and Lack of Motivation on Employee Performance at PT XYZ. The population of this study was all of the employees at PT XYZ. 76 respondents were chosen to be the sample of this research. The sampling technique used was purposive sampling. The questionnaire was a 26 -item likert scale, created by using google form, and distributed to the respondents via email. To analyze the data, research used multiple regression analysis as a test tool. Results showed that both Role Ambiguity and Lack of Motivation have a negative and significant influence on employee performance at PT XYZ, while the two other variables, Time Pressure and Workload don't have any influence on employee performance.
\end{abstract}

Keyworda: Time pressure, role ambiguity, workload, lack of motivation, employee performance

\begin{abstract}
Abstrak: Penelitian ini bertujuan untuk mengetahui pengaruh dari Time Pressure, Role Ambiguity, Workload, dan Lack of Motivation terhadap Employee Performance di PT XYZ. Populasi dari penelitian ini adalah seluruh karyawan yang bekerja di PT XYZ sejumlah 132 orang. Sample yang dipilih untuk penelitian ini berjumlah 76 responden. Teknik pengambilan sampling yang digunakan adalah purposive sampling. Kuesioner dengan 26 item pernyataan dan disajikan dengan skala likert, dibuat di google form dan disebarkan lewat email. Untuk mengolah data tersebut, penelitian menggunakan analisis regresi berganda sebagai alat ujinya. Dari penelitian didapatkan hasil bahwa Role Ambiguity dan Lack of Motivation berpengaruh negatif signifikan terhadap employee performance di PT XYZ, sedangkan kedua variabel lain, yaitu Time Pressure dan Workload tidak terdapat pengaruh.
\end{abstract}

Kata kunci: Tekanan waktu, ketidakjelasan peran, beban kerja, kurang motivasi, kinerja karyawan

\section{INTRODUCTION}

In line with the condition of a country's economic growth and technological developments, it is now very easy for consumers to get the goods or services they want. Various transactions can be done without wasting a lot of time and effort. Nowadays, online businesses such as e-commerce are growing. The demand for logistics services continues to increase, because without adequate logistics services, how can the transaction process and distribution of goods be carried out successfully.

The existence of logistics services acts as an intermediary / facilitator in the distribution of goods or services from producers to consumers by sending them to various regions. Assisted by the presence of technology development, the distribution of goods or services from big cities to remote areas or vice 
versa becomes more possible. In addition, logistics services must also ensure that the goods or services arrive on time at their destination and are responsible for maintaining the integrity and condition of the goods from damage that may occur.

As is the case with a logistics company that was founded in 1997, namely PT XYZ. This company focuses on goods delivery services for business actors in various fields, such as construction, mining, oil and gas, retail, telecommunications, and e-commerce.

The integrated service facility provided by the company is Customer Relationship Management (CRM) which will always be willing to serve and respond to customer complaints is one of the keys to the company's success with the selection of this company as one of 11 (eleven) companies in Indonesia appointed to manage PLB. by the Directorate General of Customs and Excise.

The company's success in integrated services has not been matched by the company's revenue performance. Company revenue is an indirect output of employee performance. The instability of a company's income can be influenced by several factors, one of which is the HR factor (Human Resources). The role of HR is very important in the company, because HR must be able to manage employees and create effective and efficient company conditions so that the company can run optimally.

According to Daft $(2014,11)$ "Performance is defined as the organization's ability to attain its goals by using resources in an efficient and effective manners". According to Mangkunegara (2009) employee performance is: "the quality and quantity of work achieved by an employee in carrying out his duties in accordance with the responsibilities given to him". This definition can be concluded that employee performance is the work performance or output, both the quality and quantity achieved by the unitary $H R$ for the period of time in carrying out their work tasks in accordance with the responsibilities assigned to them

There are several factors that affect employee performance, such as time pressure, role ambiguity, workload and lack of motivation. The first factor is Time Pressure. Based on research conducted by Razana Juhaida Johari (2019), time pressure is known to have a significant positive effect on employee performance. Another case with research conducted by Maria De Paola and Francesca Gioia (2016), it was found that time pressure had a significant negative effect on employee performance. However, based on research by Komang Dyah Putri Gayatri and I.D.G. Dharma Suputra (2016) shows that time pressure has no significant effect on performance.

The second factor is Role Ambiguity. Based on research conducted by Elvina Lase (2019), role ambiguity is known to have no significant effect on employee performance, but based on research by Midya Yousefi \& Abdul Abdullah (2019), it is found that role ambiguity has a significant negative effect on employee performance as well as research conducted by Arlin Adam, Andi Alim, and Dedy Maulana (2020) stated that role ambiguity is known to have a significant negative effect on employee performance.

The third factor is workload. Based on research conducted by Andrew Smith \& Hugo Smith (2017), workload is known to have a significant positive effect on employee performance. Another case with research conducted by Sulastri (2020), it was found that workload had a significant negative effect on employee performance. Meanwhile, based on research conducted by Afrina Susiarty (2019), it was found that workload had no effect on employee performance.

The fourth factor is Lack of Motivation. Based on a study conducted by Mullins (2005), it is said that the main factors of low performance are low work morale, low work motivation, feeling unappreciated and poor rewards. Unfortunately, very few studies have specifically examined this variable. Based on the description 
above, there is a research gap with previous research, therefore companies need to pay attention and try to reduce the factors of time pressure, role ambiguity, workload, and lack of motivation. Because with the increase in these things it is feared that it will reduce the overall employee performance.

This research is a replication of the research conducted by Sharmilee Bala Murali, Abdul Basit, and Zubair Hasan (2017) entitled "Impact of Job Stress on Employee Performance". As a result, time pressure and role ambiguity had a significant negative effect on employee performance, while workload and lack of motivation had no significant effect on employee performance. There are several differences between this study and the research conducted by Sharmilee et al. It can be seen in terms of sample and population where the sample they selected was 310 professionals working in various sectors in Malaysia, while in this study 76 permanent employees were selected with the population, namely all employees who work at PT XYZ. Further research from Sharmilee et al. was conducted in 2017, while this research was conducted in 2020 , so there is a possibility of differences in research results.

\section{Time Pressure}

According to Ordóñez et al $(2015,520)$ "Time pressure, by contrast, is the subjective feeling of having less time than is required (or perceived to be required) to complete a task and be motivated to complete the task in the available time." According to Maule and Svenson $(2013,27)$ "Time pressure is defined as the difference between the amount of available time and the amount of time required to resolve a decision task." According to Hsu and Fan (2010) "Time pressure is limitation of the time allotted for employees to finish their work."

\section{Role Ambiguity}

According to Robbins and Judge (2019, 404) "Role ambiguity means that the prescribed employee behaviors are not clear" According to Mishra $(2015,774)$ "Role ambiguity refers to when roles are not clear and there is some vagueness in roles." According to Chiocchio et al. $(2015,254)$ "Role ambiguity refers to a lack of clarity about the behaviors expected in a specific job."

\section{Workload}

According to Robbins (2019) "Workload referencing to the intensity of job assignments. It is a source of mental stress for employees. The workload refers to the amount of work one person has to do in order to complete his task. " According to Green $(2016,373)$ "Workload refers to the amount to be completed within a particular time period" According to Morris (2007) "The workload is the total amount of work that must be completed by individuals within a specified period"

\section{Lack of Motivation}

According to Aditomo $(2015,205)$ lack of motivation or demotivation "refers to diminished effort and interest" According to Sahragard $(2013,309)$ lack of motivation or demotivation is "demotivation refer to a situation in which motivation must exist before there can be a subsequent decrease" According to Dornyei $(2001,143)$ lack of motivation or demotivation is "specific external forces that reduce or diminish the motivation basis of a behavior intention or an ongoing action"

\section{Employee Performance}

According to Christian (2018, 18) "Employee performance is the actual achievement of the employee compared to the expected performance of the employee" According to Sharma $(2016,33)$ "The term performance refers to one's skill, abilities in meeting the requirements of the job which one is holding currently." According to Daft $(2014,11)$ "Performance is defined as the organization's ability to attain its goals by using resources in an efficient and effective manners" 


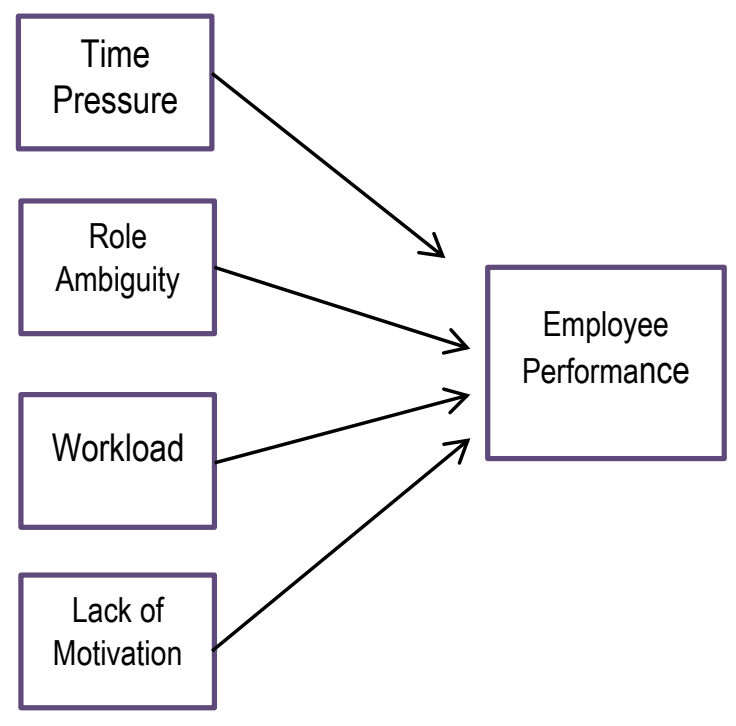

Figure 1 Research Model

\section{METHODS}

This research is in the form of a causal relationship, which means that it is a study of the cause and effect relationship between the independent variable and the dependent variable. The method in this research is a descriptive analysis method which is a method to describe or analyze a research result but is not used to make broader conclusions (Sugiyono, 2017: 147). The object of this research is PT XYZ which is located in South Jakarta, the Special Capital Region of Jakarta.

Sugiyono $(2017,80)$ states that population is a generalization area consisting of objects or subjects that have certain qualities and characteristics that are determined by researchers to be studied and then draw conclusions. The population in this study were 132 employees who worked at PT XYZ.

While the sample according to Sugiyono $(2017,81)$ is part of the number and characteristics of the population. The number of samples studied was 76 permanent employees who worked at PT XYZ. The sampling technique used in this study is non-probability sampling with a purposive sampling method. According to
Sugiyono $(2017,85)$ purposive sampling is a sampling technique with certain considerations. The sample criteria set by the researcher are permanent employees in the company.

Time Pressure $(\mathrm{X} 1)$ is a condition that arises when a person must be able to complete a task or job within a certain time limit which is usually less than expected. Role ambiguity (X2) is a condition in which employees do not receive adequate information, resulting in a lack of understanding of their roles, jobs, direction of goals, and company policies that govern them. Workload (X3) is a number of activities or tasks that must be completed by workers within a certain period of time which in its implementation demands the ability of an individual. Lack of Motivation (X4) is a situation where there is a decrease in motivation and morale which will have a negative influence on work implementation. Employee Performance $(Y)$ is an output from employees that cannot be separated from the results achieved, and is effective in increasing productivity on the tasks and responsibilities assigned to them.

\section{RESULT}

The descriptions of respondent data in this study were divided by the researcher into several categories with different criteria, including gender, age, and position. Based on the research results, in Hypothesis 1 there is no effect of time pressure on employee performance at PT XYZ. This is evidenced by the results of the $T$ test which shows the sig value of $0.072>0.05$ and the t value of $1.825<t$ table 1.99394, so that Ho is accepted, which means that the time pressure variable $(\mathrm{X} 1)$ has no effect on the employee performance variable $(\mathrm{Y})$.

Based on the research results, in Hypothesis 2, there is an effect of role ambiguity on employee performance at PT XYZ. This is evidenced by the results of the $T$ test which shows the sig value of $0.000<0.05$ and the $t$ value of $3.688>t$ table 1.99394 in the negative 
direction, so that Ho is rejected, which means the variable role ambiguity $(X 2)$ has a significant negative effect on employee variables. performance $(Y)$.

Based on the research results, in Hypothesis 3 there is no effect of workload on employee performance at PT $X Y Z$. This is evidenced by the results of the $T$ test which shows the sig value of $0.362>0.05$ and the $t$ value of $0.917<t$ table 1.99394 , so that $\mathrm{Ho}$ is accepted, which means that the workload variable $(X 3)$ has no effect on the employee performance variable $(Y)$.

Based on the research results, in Hypothesis 4, there is an effect of lack of motivation on employee performance at PT XYZ. This is evidenced by the results of the $T$ test which shows the sig value of $0.008<0.05$ and the $t$ value of $2.746>t$ table 1.99394 in the negative direction, so that $\mathrm{Ho}$ is rejected, which means that the lack of motivation (X4) variable has a significant negative effect on the variable. employee performance $(\mathrm{Y})$.

\begin{tabular}{cccc}
\multicolumn{4}{c}{$\begin{array}{c}\text { Tabel Koefisien Regresi } \\
\text { Time Pressure, Role ambiguity, Workload dan Lack of Motivation }\end{array}$} \\
\hline Model & $\begin{array}{c}\text { Unstandardized } \\
\text { Coefficients }\end{array}$ & & \\
\cline { 2 - 4 } & $\mathbf{B}$ & $\mathbf{T}$ & Sig \\
\hline (Constant) & 24,662 & 6,573 & 0,000 \\
Time Pressure & 0,236 & 1,825 & 0,072 \\
Role Ambiguity & $-0,462$ & $-3,688$ & 0,000 \\
Workload & 0,129 & 0,917 & 0,362 \\
Lack of Motivation & $-0,343$ & $-2,746$ & 0,008 \\
\hline Sumber: Hasil Pengolahan Data & & &
\end{tabular}

\section{CONCLUSIONS}

The results of this study can be concluded as follows:

1. Time pressure has no effect on employee performance at PT XYZ. This statement is supported by research conducted by Gayatri (2016) on different objects.

2. Role ambiguity has a significant negative effect on employee performance at PT XYZ. This statement is supported by research conducted by Yousefi and Abdullah (2019) on different objects.

3. Workload has no effect on employee performance at $\mathrm{PT} X Y Z$. This statement is supported by research conducted by Susiarty (2019) on different objects.

4. Lack of Motivation has a significant negative effect on employee performance at PT XYZ.

The limitations that occur during this research process can be described as follows:

1. There are limitations in time, money, and energy. So that the questionnaire is not possible to distribute directly to respondents in written form.

2. The number of respondents who became the sample for this study was 100 people, but in fact only 76 questionnaires were returned to the researcher.

3. Limited information and theory availability for several variables. This is because it is still very little discussed and researched.

4. Limited data obtained from the object of research. This is because the data is said to be very internal in nature and confidential (confidential) so that the object of research cannot disseminate it to the public.

Here are some forms of recommendations that might be used as a reference for researchers who want to carry out further research:

1. Expanding the number and using a larger sample for use in further research, so that the results can be more accurate and more representative of the entire population.

2. In further research, it is better to expand the scope of research

3. Adding independent variables outside the variables that have been used that can affect employee performance.

The following are some of the recommendations PT XYZ could consider:

1. Time pressure does not affect employee performance of employees at PT XYZ. The 
pressure on employees, especially in terms of time, may be great, but it is considered part of the job. Their satisfaction with their work as evidenced by their relatively high performance, causes it not to affect them.

2. Role ambiguity affects employee performance of employees at PT XYZ. It is important for organizational management to minimize role ambiguity by conveying and communicating clear roles and positions, related to duties, jobs, and regulations to all employees, in order to increase their performance.
3. Workload has no effect on employee performance of employees at PT XYZ. Most of them do get a large workload, but it is considered an obligation and a consequence of what they do. The existence of regular work rotations also causes employees to feel variations in workloads.

4. Lack of Motivation affects employee performance of employees at PT XYZ. Organizations need to minimize this by providing motivation in various forms, both financial and non-financial, and always giving appreciation to employees for the good work that has been done.

\section{REFERENCES:}

Aditomo, A. 2015. Students' Response to Academic Setback: "Growth Mindset" as A Buffer Against Demotivation. International Journal of Educational Psychology, 4(2).

Chiocchio, F., Kevin Kelloway, and Brian Hobbs. 2015. The Psychology and Management of Project Teams. New York: Oxford University Press.

Christian, F. 2018. Leadership and Motivation to Performance Employee in Papua Province. International Journal Economics Management and Social Science Vol. 1

Daft, R. 2014. New Era of Management. Canada: South-Western Cengage Learning.

Dörnyei, Z. 2001. Motivational Strategies in the Language Classroom. Cambridge: Cambridge University Press.

Gayatri, K. D. P., dan Suputra, I. D. G. D. 2016. Pengaruh Struktur Audit, Tekanan Waktu, Disiplin Kerja dan Komitmen Organisasi pada Kinerja Auditor. E-Jurnal Akuntansi, 1366-1391.

Green, Simon., Rob Lewis, Julia Willerton, Dave Cox and Kevin Silber. 2016. Oxford AQA Psychology A Level Year 2. Glasgow: Oxford University Press.

Hsu, M. L., and Hsueh-Liang Fan. 2010. Organizational Innovation Climate and Creative Outcomes: Exploring The Moderating Effect of Time Pressure. Creativity Research Journal, 22(4), 378-386.

Maule, A. J., and Ola Svenson. 2013. Time Pressure and Stress in Human Judgment and Decision Making. New York: Springer Science \& Business Media.

Mishra, Shruti. 2015. Discussion on Conflict Management with Special Emphasis on Role Conflict: Scope in Future Study. International Journal of Advanced Research, Volume 3, Issue 10,772 - 777. ISSN 2320-5407.

Morris, R., Padraig MacNeela, Anne Scott, Pearl Treacy, and Abbey Hyde 2007. Reconsidering The Conceptualization of Nursing Workload: Literature review", Journal of Advanced Nursing, 57(5), pp. 463-471.

Muraale, S., Abdul Basit, and Zubair Hassan. 2017. Impact of Job Stress on Employee Performance. International Journal of Accounting and Business Management, 5(2), 13-33.

Ordóñez, L. D., Lehman Benson, and Andrea Pittarello. 2015. Time-pressure Perception and Decision Making. The Wiley Blackwell handbook of Judgment and Decision Making, 517-542.

Robbins, S., and Timothy A. Judge. 2020. Organizational behavior 18ed. New Jersey.

Sahragard R., and Zahra Alimorad. 2013. Demotivating Factors Affecting Iranian High School Students' English Learning. In: Cortazzi M., Jin L. (eds) Researching Cultures of Learning. Palgrave 
Macmillan, London

Sharma, Dr. F. C. and Anju Agarwal. 2016. Human Resource Management (Latest Edition). SBPD Publications.

Sugiyono. 2017. Metode Penelitian Kuantitatif, Kualitatif dan R\&D. Bandung: CV. Alfabeta

Susiarty, A., Lalu Suparman, dan Mukmin Suryatni. 2019. The Effect of Workload and Work Environment on Job Stress and Its Impact on The Performance of Nurse Inpatient Rooms at Mataram City General Hospital. Scientific Research Journal. 7(6)

Yousefi, M., and Abdul G. Abdullah. 2019. The Impact Of Organizational Stressors On Job Performance Among Academic Staff. International Journal of Instruction, No:3 July 2019, pp. 561-576, -ISSN: 1694-609X 
